\title{
Graduated Control and Beyond: The Evolving Government-NGO Relations
}

\section{Fengshi Wu and Kin-man Chan}

\section{(2) OpenEdition \\ 1 Journals}

\section{Electronic version}

URL: https://journals.openedition.org/chinaperspectives/5928

DOI: 10.4000/chinaperspectives.5928

ISSN: 1996-4617

\section{Publisher}

Centre d'étude français sur la Chine contemporaine

\section{Printed version}

Date of publication: 1 October 2012

Number of pages: 9-17

ISSN: 2070-3449

\section{Electronic reference}

Fengshi Wu and Kin-man Chan, "Graduated Control and Beyond: The Evolving Government-NGO Relations", China Perspectives [Online], 2012/3 | 2012, Online since 01 October 2015, connection on 03 January 2022. URL: http://journals.openedition.org/chinaperspectives/5928 ; DOI: https://doi.org/ 10.4000/chinaperspectives.5928 


\title{
Graduated Control and Beyond
}

\author{
The Evolving Government-NGO Relations
}

\author{
FENGSHI WU AND KIN-MAN CHAN
}

\begin{abstract}
Despite recent policy changes, governmental monitoring and control of grassroots NG0s remain pervasive and effective to a large extent in China. The enforcement of control over NGOs is complicated by at least three layers of factors: First, multiple agencies are involved in NGO control without a centralised norm. Second, government-NGO interactions vary across cases and are deeply rooted in local political contexts. Last, but not least, since the NGO community at its origin is highly diverse, NGOs' responses to various types of governmental control differ, which in turn triggers further complications. The main findings of this research are based on interviews with 60 NG0 staff, as well as with civil affairs officials in 17 provinces from January 2011 to May 2012.
\end{abstract}

KEYWORDS: state-society relations, NG0, Chinese politics, social regulation.

$n$ April 2012, China's Ministry of Civil Affairs completed the selection of

377 projects from 901 applications submitted by officially recognised

social organisations across the country, and distributed 200 million yuan of the central fiscal budget - the "special fund for social organisations' participation in service delivery" - to support these selected projects. ${ }^{(1)}$ On 30 June, the Chengdu Social Organisation Development Fund was established with a starting budget of 300 million yuan, the first of its kind in the country fully supported and financed by a provincial capital city government. (2) Starting from 1 July, the Guangdong provincial government relinquished the old registration regulations and made it possible for social organisations to obtain legal status without a "professional supervisory unit" (yewu zhuguan danwei). (3) Despite the dramatic events of last year, including self-imposed exile by a leading AIDS activist and the Guo Meimei incident, followed by scandals within the China Charity Federation and warning signals from the authorities due to the Arab Spring earlier this year, 2012 seems to be gradually providing more fertile ground for grassroots social organisations and the development of civil society.

As with Chinese politics in general, the issue of governing social organisations is filled with complex and sometimes contradictory trends. Thus, China observers have arrived at different conclusions on the topic. Some praise "remarkable" improvements in recent years regarding the regulatory framework of social organisations, while many remain very cautious about the overall policy environment for grassroots non-governmental organisations (NCOs), social activism, and advocacy. ${ }^{(4)}$ Instead of relying on reading the nuances in policy documents, this research agrees with Guosheng Deng's approach of "in-depth exploration of the unwritten or unpublished rules" in examining government-NGO relations, and engages the debate by examining the interactions between governmental agencies and NGOs in daily practice. ${ }^{(5)}$ To do so, the authors during the period of January 2011 to May 2012 interviewed 60 activists and staff from 17 provinces, who explained how they interacted with a variety of governmental agencies ranging from professionally relevant ones to those related to public security, foreign affairs, taxation, statistics, and state security. ${ }^{(6)}$ In addition, the paper benefited from field research trips to Guangxi in March 2011, Heilongjiang in August 2011,
Guangdong in March 2012, Sichuan in April 2012, Shanghai in May 2012, and Gansu in July 2012, during which the authors met with leading activists, civil affairs officers, and peer researchers in these provinces and discussed changing the local policies and policy environment for NGO development. ${ }^{(7)}$

This research seeks patterns in the dynamic relationship between local authorities and NGOs, and has found that, at the operational level, governmental monitoring and control of grassroots NGOs remain pervasive and effective to a large extent, in spite of recent promising changes in policies at both the national and provincial levels. The enforcement of such control is complicated by at least three layers of factors: First, the Chinese state system is massive and often fragmented, and NGO control and regulation therefore faces the common challenges of inter-bureaucratic and centrallocal coordination. Second, since the NGO community at its origin is highly diverse and continues to grow, NGOs' responses to various kinds of govern-

1. For a full announcement of the selection results, see www.chinanpo.gov.cn/2351/53036/ index.html (consulted on 16 August 2012).

2. Chengdu municipal government official website, www.chengdu.gov.cn/news/detail.jsp?id=644642 (consulted on 16 August 2012).

3. Scheme of Incubation, Development, and Regulation of Social Organisations, Guangdong Provincial Bureau of Civil Affairs, www.gdmjzz.gov.cn (consulted on 16 August 2012).

4. Professor Karla Simon presented her positive assessment of the changes in regulations of social organisations in China and called 2011 "the remarkable year for China's civil society" at New York University Law School on 6 March 2012. However, many remain cautious about the actual implementation and effects of recent regulatory changes. For example, Shanghai Fudan University professor Yijia ling has correctly pointed out the resilience of state power and comprehensive restrictions over social organisations embedded in the recent experiments of governmental outsourcing and competitive contracting in social service delivery (Yijia Jing, "Outsourcing in China: An Exploratory Assessment," Public administration and development, vol. 28, no. 2, 2008, pp. 119128; Yijia Jing and Bin Chen, "Is Competitive Contracting Really Competitive? A Case Study of Restructuring Government-Nonprofit Relations in Shanghai," Working Paper of the Center for Nonprofit Strategy and Management, Baruch College, City University of New York, 2009).

5. Guosheng Deng, "The Hidden Rules Governing China's Unregistered NGOs: Management and Consequences," China Review, vol. 10, no. 1, Spring 2010, pp. 183-206.

6. Please refer to the website of the Centre for Civil Society Studies CUHK for detailed information on the visiting fellow program, which brings 50-60 NCO representatives to Hong Kong each year: http://ccss-cuhk.com (consulted on 16 August 2012).

7. Some of the field trips were funded by the Hong Kong General Research Fund Grant (Project \# 453509, Principle Investigator - Fengshi Wu), "Ideational Dimensions of Civil Society: An Empirical Research of the Political Reflection and Collective Identity of Social Entrepreneurs in China" (September 2009-August 2012). 
mental control measures differ, which in turn triggers further complications. Last but not least, as voluntarism and establishing NGO are becoming widespread social phenomena in China, the politics cantering NGOs is gradually taking deeper root in local contexts.

This paper consists of four main parts. Part one reviews the evolution of the regulatory framework of social organisations in contemporary China in general over time and introduces the pattern of graduated control over NGOs in particular. It also discusses various theoretical perspectives on the topic. Part two further explores the differentiated interactions between governmental agencies and NGOs, and outlines the main factors that shape such interactions. Part three introduces the temporal dimension of the government-NGO relationship, and examines various NGO reactions to the state's graduated control. These responses trigger new adjustments in state behaviour and the enforcement of the control policy. The last part calls attention to policy innovations and changes in governmental attitudes towards the issue of NGO development in several provinces and municipalities, and argues that the overall control over NGOs is modified by local political contexts.

A note of definition is in order. The paper defines NGOs as voluntarybased, not-for-profit, and private organisations that exhibit a minimum level of institutionalisation and self-governance. ${ }^{(8)}$ In comparison, a "social organisation" is a much broader category, including but not limited to NGOs, professional and business associations, hobby groups, and community-based organisations. In the Chinese context, the definition of NGO is further modified by two specifications: Firstly, as current Chinese laws make it extremely difficult to register as an NGO, most existing and functioning NGOs have legal status as other types of legal entity. Therefore, the paper considers any legally registered and/or publicly recognised organisation an NGO as long as it in practice fulfils the requirement of being private, voluntary-based, not-for-profit, and with a minimum level of institutionalisation and selfgovernance. Secondly, the paper uses three criteria to differentiate NGOs from quasi-governmental, semi-state-affiliated, or state-sponsored organisations in practice. These criteria include: 1) the organisation is neither initiated nor registered by a concurrent governmental official or party cadre as its sole legal representative; 2 ) the initial funding does not come from the government or part of a governmental project; and 3) there is no mandatory party organ within the organisation.

In the official policy language, three types of social organisations are eligible and required to register with the civil affairs bureaus: 1) shehui tuanti - membership-based associations; 2) minban feiqiye danwei- non-governmental, non-profit organisations; and 3) jijin hui-charity foundations. The first type is most highly restricted, as they are seen as the most effective means of social mobilisation and therefore a threat to political authority. Most of the NGOs analyzed here would fall into the second category if they could obtain legal status. Some private charity foundations, such as the One Foundation, Narada Foundation, and Vantone Foundation, find themselves advocating for policy changes in a similar way to NGOs. However, the number, scope, and characteristics of these foundations are different from those of grassroots NGOs, and thus they are not the focus of this paper. ${ }^{(9)}$

\section{Social organisation regulation in China: $A$ brief review}

Several benchmark studies point out that a nascent civil society emerged in the late Qing period or even earlier. ${ }^{(10)}$ Chambers of commerce, guilds, kinship organisations, religious organisations, charity groups, and intellectuals' associations were not only active in their own arenas, but were also involved in local governance and political activities. These groups continued to engage in politics during the Republican period by organising events such as protests and strikes around the May Fourth Movement of 1919 and the May Thirtieth Massacre of 1925. Only after the Nationalist Party established its government in Nanjing in 1927 and started to purge the Communists was there a counter-trend in state-society relations in modern China (Strand, 1989; White et al., 1996). When the Chinese Communist Party (CCP) took power in 1949, civil society was further suppressed, if not completely eradicated. In 1950, Provisional Regulation for Registration of Social Organisations (Shehui tuanti dengji zanxingfa) was promulgated, and by 1964 the responsibility of overseeing these groups was assigned to "supervisory units" (zhuguan danwei) such as state-owned enterprises and "people's organisations" (renmin tuanti), e.g., the Communist Youth League, the All China Women's Federation, the All China Association of the Disabled, and the $\mathrm{Na}$ tional Federation of Industry and Commerce.

The Regulation on the Registration and Management of Social Organisations promulgated in 1989 after the Tiananmen crackdown was the first attempt of re-organising state-society relations since the end of the Cultural Revolution. Set against the background of the June Fourth movement and the preceding decade of political liberalisation, it was meant to strengthen the state's control over the reviving civil society forces through regular measures. This Regulation was amended in 1998 in the wake of the Falun Gong protests that took the central political authority by complete surprise. There have been high expectations of a new round of revisions to the Regulation since then, but none has appeared to date. As mentioned at the beginning, Guangdong in 2012 became the first province to establish and put in force a new set of rules regarding social organisation registration and regulation at the provincial level. Such could be interpreted as a signal for further regulatory reform at the national level.

There are two defining characteristics of the 1989/1998 Regulation: exclusion and dual supervision. ${ }^{(11)}$ First, it stipulates that only one social organisation is allowed to register within an administrative sector at each level. For example, if there is already in existence an environmental protection association registered at the Beijing municipal level, no other social organisation working in the same issue area for the entire city will be given official approval. Simply put, with the existing government-established social organisations (also known as government organised NGOs - GONGOs) in almost every sector and at every administrative level, there is little institutional space for any new, voluntary-based, and non-government initiated organisations to obtain formal registration. This exclusive provision has

8. Lester M. Salamon and Helmut K. Anheier, Defining the Nonprofit Sector, Manchester, Manchester University Press, 1997, pp. 33-34.

9. The sector of private charity foundations has been growing fast over the last five years, and together they have successfully bargained tax rebates with the government. See Jianfeng Zhang, "Report on 'Tax-Protest' of Chinese Foundation," Nan Feng Chuang Magazine, 11 February 2010.

10. William T. Rowe, Hankow: Commerce and Society in a Chinese City: 1796-1895. Stanford (CA), Stanford University Press, 1984; Mary B. Rankin, Elite Activism and Political Transformation in China: Zhejiang Province, 1865-1911, Stanford (CA), Stanford University Press, 1986; William T. Rowe, "The Problem of 'Civil Society' in Late Imperial China," Modern China, vol. 19, no. 2, 1993, pp. 139-57; David Strand, "Civil Society" and "Public Sphere" in Beijing, 1919-1989, Durham (NC), Duke University, 1990; Heath B. Chamberlain, "On the Search for Civil Society in China," Modern China, vol. 19, no. 2, 1993, pp. 199-215.

11. Elizabeth Knup, "Environmental NGOs in China: An Overview," China Environment Series, no. 1, 1997, pp. 9-15; Qiusha Ma, "The Governance of NGOs in China since 1978: How Much Autonomy?," Nonprofit and Voluntary Sector Quarterly, vol. 31, no. 3, 2002, pp. 305-28; Nick Young, "NCOs: The Diverse Origins, Changing Nature and Growing Internationalization of the Species," China Development Brief, 2004. 


\begin{tabular}{|l|l|l|l|}
\hline \multicolumn{1}{|c|}{ Business nature } & \multicolumn{1}{c|}{ Main funding source } & \multicolumn{1}{c|}{ Scale } & Level of Control \\
\hline \multirow{2}{*}{ Category I: Service delivery } & $\begin{array}{l}\text { Government, GONGO, } \\
\text { official foundations } \\
\text { in residential community }\end{array}$ & $\begin{array}{l}\text { Medium to large NGO, } \\
\text { across communities }\end{array}$ & Ledium \\
\hline $\begin{array}{l}\text { Category II: Service, } \\
\text { public outreach, and advocacy } \\
\text { in non-sensitive areas }\end{array}$ & $\begin{array}{l}\text { Domestic enterprises, } \\
\text { domestic private foundations }\end{array}$ & $\begin{array}{l}\text { NGO and/or } \\
\text { cross-regional network }\end{array}$ & Medium \\
\hline $\begin{array}{l}\text { Category III: Advocacy in } \\
\text { political/religious/ethnic } \\
\text { and/or other sensitive areas }\end{array}$ & $\begin{array}{l}\text { Private donations, } \\
\text { international NGO } \\
\text { and foundations }\end{array}$ & $\begin{array}{l}\text { NGO, informal groups, } \\
\text { and/or network }\end{array}$ & High \\
\hline
\end{tabular}

* Note: Based and developed upon the model in Kin-man Chan, "Commentary on Hsu: Graduated Control and NGO Responses - Civil Society as Institutional Logic," Journal of Civil Society, vol. 6, no. 3, 2010, pp. 301-306.

largely curbed the growth of associations and any constructive competition between civic associations.

In addition, the Regulation also stipulates the practice of dual supervision to grant registration. Each organisation needs to find a state agency to be its "professional supervisory unit" before applying for registration with the civil affairs departments at different administrative levels. These supervisory units assume not the professional/technical but the political responsibility for inspecting the activities and finances of civic groups, making sure no illegal - or more importantly, no anti-governmental - activities take place. Thus, governmental agencies have little incentive to sponsor civic organisations, except when material interests or personal connections are involved. (12) Under such arrangements, the state is accustomed to regulating the development of social groups strictly in line with its main policy framework. ${ }^{(13)}$

By the end of the 1990s, most scholars of state-society relations in China viewed the exclusion of genuine citizen initiatives and dual supervision as exemplifying state corporatism - a system of interest representation in which a limited number of constituent units outside of the state are recognised by the state, and therefore state agencies remain the monopolising representatives of respective sectors. ${ }^{(14)}$ Entering the new millennium, the civil society sector has become unprecedentedly active in tandem with deep socio-economic transformations throughout the country. Although the Chinese state recognises the need to create a new social sector to cater to the needs of the population as the vertical rule of the danwei system deteriorates, it still worries that this sector will turn into a subversive force when given too much autonomy. This ambivalence has created a lot of inconsistencies and even conflicts among state agencies concerning matters related to NGOs. An increasing body of literature has emerged and highlights NGOs' autonomy and capacity to negotiate political space with the state. ${ }^{(15)}$ Scholars have applied "fragmented authoritarianism" to explain how NGOs, particularly those leading the anti-dam construction movements, are able to utilise limited political opportunity and form alliances with the media, experts, and reform-minded officials to exert pressure on targeted large companies or specific state agencies. ${ }^{(16)}$

Moving to the side of the state, although inter-departmental conflict of interest and central-local bargaining are salient features of the regime, many have pointed out the Chinese state's capacity for learning, adaptation, and improving policy effectiveness. ${ }^{(17)}$ In the field of social regulation, a policy of "graduated control" (fenlei guanzhi 分类管治) has emerged and has been implemented effectively. ${ }^{(18)}$ Kang and Han argue that the Chinese authorities differentiate social groups into various types and exercise different levels of control accordingly. To some extent, a policy solution of remaining vague at the overall level and striking deals in individual cases firmly reflects the political pragmatism that has guided China's miraculous economic reform over the past 30 years.

Kang and Han's framework covers a wide range of social organisations, including GONGOs, NGOs, hobby groups, business associations, and informal groups. We find this approach of interpreting policies and state intentions

12. Fengshi Wu, "Environmental GONGO Autonomy: Unintended Consequences of State Strategies in China," Journal of the Good Society, vol. 12, no. 1, 2003, pp. 35-45.

13. Xiaoguang Kang, "Social Organisations in China's Transitional Period," in Zhongguo qingshaonian fazhan jijinhui, jijinhui fazhan yanjiu weiyuanhui (China Youth Development Foundation and Research Committee on the Development of Foundations) (ed.), Chu yu shi zi lu kou de Zhongguo she tuan (China's social organisations at the crossroads), Tianjin, Tianjin renmin chuban she, 2001, pp. 3-29.

14. Jonathan Unger and Anita Chan, "Corporatism in China: A Developmental State in an East Asian Context?," in B. McCormick and J. Unger (eds.), China After Socialism: In the Footsteps of East Europe or East Asia?, Armonk (NY), M. E. Sharpe, 1996, pp. 95-129; Michael Frolic, "State-Led Civil Society," in T. Brook and M. Frolic (eds.), Civil Society in China, Armonk (NY), M.E. Sharpe, 1997; Margaret Pearson, China's New Business Elite, Berkeley, University of California Press, 1997.

15. Tony Saich, "Negotiating the State:The Development of Social Organizations in China," The China Quarterly, vol. 161, 2000, pp. 125-141; Jennifer Turner, "Small Government, Big and Green Society: Emerging Partnership to Solve China's Environmental Problems," Harvard Asia Quarterly, vol. VIII, no. 2, 2004; Kin-man Chan, "The Development of NGOs under a Post-Totalitarian Regime: The Case of China," in Robert Wellner (ed.), Civil Life, Globalization, and Political Change in Asia: Organizing Between Family and State, New York, Routledge, 2005, pp. 20-41; Kin-man Chan, "Chinese NGOs Strive to Survive," Social Transformations in Chinese Societies, vol. 1, 2005, pp. 131-159; Jude Howell, "Civil Society in China: Chipping away at the edges," Development, vol. 50, no. 3, 2007, pp. 17-23.

16. Andrew Mertha, China's Water Warriors: Citizen Action and Policy Change, Ithaca (NY), Cornell University Press, 2008; Kin-man Chan and Yan Zhou, "Political Opportunity and the Anti-dam Construction Movement in China," in Zhidong Hao and Sheying Chen (eds.), Social Issues in China: Gender, Ethnicity, Labour, and the Environment, New York, Springer, forthcoming.

17. DaliYang, Remaking the Chinese Leviathan, Stanford (CA), Stanford University Press, 2004; Kellee S. Tsai, Capitalism without Democracy: The Private Sector in Contemporary China, Ithaca (NY), Cornell University Press, 2007; Kun-Chin Lin, "Politics and the Market in Twenty-First-Century China: Strategies of Authoritarian Management of State-Society Relations," Political Studies Review, vol. 10, no. 1, 2012, pp. 73-84

18. Xiaoguang Kang and Han Heng, "Graduated Controls: The State-Society Relationship in Contemporary China," Modern China, vol. 34, no. 1, 2008, pp. 36-55. 
Table 2 - Content and relevant agencies of NGO control

\begin{tabular}{|c|c|c|c|c|}
\hline \multirow{2}{*}{ Level of control } & \multicolumn{4}{|c|}{ Type of control } \\
\hline & $\begin{array}{l}\text { Sectoral supervisor and } \\
\text { civil affairs bureau }\end{array}$ & Public security & $\begin{array}{l}\text { Statistics, taxation, and } \\
\text { other regulatory agencies }\end{array}$ & State security \\
\hline Low & $\begin{array}{c}\text { Minimum document-based } \\
\text { supervision, irregular } \\
\text { meetings }\end{array}$ & Rare interaction & No interaction & No interaction \\
\hline Medium & $\begin{array}{l}\text { Frequent document-based } \\
\text { supervision and meetings }\end{array}$ & $\begin{array}{l}\text { Irregular personal } \\
\text { meetings, or } \\
\text { harassment }\end{array}$ & $\begin{array}{l}\text { Warning, irregular } \\
\text { requests or visits }\end{array}$ & Irregular interaction \\
\hline High & $\begin{array}{l}\text { Scrutiny, official warning, } \\
\text { temporary closing down }\end{array}$ & $\begin{array}{l}\text { Personal harassment, } \\
\text { or office raid }\end{array}$ & Frequent request & Frequent interaction \\
\hline
\end{tabular}

useful and accurate for understanding government-NGO relations in particular. It echoes the theme of "embedded activism" proposed by Ho and Edmonds, which captures the tense and interactive relationship between local governmental agencies, contextual factors, and NGOs. ${ }^{(19)}$ Recent empirical research further confirms the argument that NGOs and local authorities interact and negotiate on an almost daily basis. ${ }^{(20)}$ As the NGO sector has grown, the state's learning of it has been enhanced. Although macrolevel policies remain vague and out of date, the actual enforcement of NGO control on the ground has become more diversified and thus responsive to the particulars of local conditions and the targeted NGOs.

Based on direct communication and interviews with grassroots NGOs, this paper finds a pattern of graduated and targeted control over NGOs at the operational level in China. Table 1 demonstrates the perceived risk of NGOs and the parallel level of control exercised by the state. Three major factors determine the level of governmental control and monitoring: business nature, funding source, and scale. Business nature stands out as the most significant factor, because it also to a great extent determines the NGO's funding sources and organisational scale. The Chinese government allows, and increasingly supports, NGOs that provide services in issue areas such as poverty reduction, elderly care, women's and children's programmes, and basic education. Most such Category I NGOs have received and are increasingly eligible to apply for funding from governmental agencies (e.g., civil affairs bureaus), GONGOs (e.g., official associations for the disabled), and official charities (e.g., Red Cross China). Once fully funded with official money, such NGOs are often considered a service arm of the administration. In terms of scale, small NGOs working at the community level, particularly the urban residential compounds (xiaoqu), are seen as the least threatening to the regime. If they provide valuable social services, then some local governments, such as those in Shenzhen and Shanghai, have even begun to simplify the registration requirements. The Chinese state still finds large NGOs that operate at the municipal or provincial level and serve populations across regions difficult yet necessary to control, even if they only aim at providing services within the boundaries of governmental policies. In the same vein, existing laws forbid NGOs with a nationwide membership base and cross-regional NGO alliances.

The government exercises close surveillance, delays registration application, and even impedes the development of Category II NGOs that serve marginal groups such as migrant workers, peasants living with AIDS, or the urban poor affected by forced house-dismantlement or industrial pollution. This group of NGOs serves targeted populations not only by direct delivery of care and service, but also by public education on the issues and even pol- icy advocacy. The goal of their work requires them to bring in outside technical support, experts, and professionals, such as social workers, medical professionals, lawyers, media, and public campaigners. Most of them are therefore not bound to one community or a specific group of victims, and they attract more attention from the supervising authorities compared with Category I NGOs. Among Category II NGOs, those who are able to solicit donations from domestic private enterprises or charities incur relatively lower government monitoring. More vigorous government surveillance is exercised over NCOs that receive funding from overseas foundations or governments. Since March 2010, Chinese NGOs have been required to go through a notarisation process for any projects funded by overseas entities. ${ }^{(21)}$ Close to one-third of the $60 \mathrm{NGO}$ staff interviewed for our research reported that their funding had been frozen or significantly cut due to this policy change.

Finally, the government ruthlessly cracks down on Category III NGOs and networks that are perceived as involved in the democratic movement, religious mobilisation, ethnic separatism, human rights, or anything that is seen as damaging China's international image and internal regime legitimacy, such as the Beijing Gongmeng Legal Research Centre and other rights advocacy groups. ${ }^{(22)}$ Such organisations are usually not able to establish and maintain formal organisational structures, and they most often obtain funding from overseas sources.

In practice, the above three factors together affect how the Chinese government views and monitors an effective NGO. For example, a fast-growing NGO specialising in legal assistance for discrimination victims should be regarded as having high risk given the fact that it conducts rights advocacy, receives funds from foreign foundations, and has established affiliated teams in multiple cities. ${ }^{(23)}$ NGOs such as the Beijing Senior Citizen Cooperative should be regarded as low risk, as they work in the area of elderly services,

19. Peter Ho and Richard L. Edmonds, China's Embedded Activism: Opportunities and Constraints of A Social Movement, London/New York, Routledge, 2008

20. Timothy Hildebrandt, "The Political Economy of Social Organization Registration in China," The China Quarterly, vol. 208, 2011, pp. 970-89; Anthony J. Spires, "Contingent Symbiosis and Civil Society in an Authoritarian State: Understanding the Survival of China's Grassroots NGOs," American Journal of Sociology, vol. 117, no. 1, 2011, pp. 1-45; Fengshi Wu, "Transnational Advocacy and the State: AIDS Prevention in China," Journal of Contemporary China, vol. 20, no. 71, 2011, pp. 621-37.

21. Xinhua News online, http://news.xinhuanet.com/yuqing/2012-02/06/c_122659474_2.htm (consulted on 16 August 2012).

22. Hualing Fu and Richard Cullen, "Weiquan (Rights Protection) Lawyering in An Authoritarian State: Building A Culture of Public-Interest Lawyering," The China Journal, vol. 59, January 2008, pp. 11127; Eva Pils, "China's Troubled Legal Profession," Far Eastern Economic Review, May 2008, available at SSRN: http://ssrn.com/abstract=1563922 (consulted on 16 August 2012).

23. The name of this case is kept unidentified for the purpose of protection. 
Table 3 -The temporal dimension of the graduated control of category II NGO

\begin{tabular}{|c|c|}
\hline Level of control & Organizational development \\
\hline Low & $\begin{array}{l}\text { Early stage, limited visibility and outreach, } \\
\qquad 1-2 \text { years }\end{array}$ \\
\hline Medium & $\begin{array}{l}\text { Sustainable development and } \\
\text { continual growth, 3-8 years }\end{array}$ \\
\hline High & $\begin{array}{l}\text { Relatively higher level of capacity, playing } \\
\text { a leadership role among local NGO }\end{array}$ \\
\hline
\end{tabular}

receive funds from the Beijing authorities and domestic corporate charity foundations such as the Guangdong Harmonious Community Foundation, and limit their work strictly to the residential community level.

\section{Graduated control in operation: Multiple dimensions and agencies}

The framework of graduated control provides a theoretic overview of governmental attitudes and behaviour towards NGO development in China. This section substantiates this framework by providing the content of the three levels of NGO control and explicates the various state actors involved in the process.

The enforcement processes of NCO control in reality are complex and operated by multiple governmental agencies without a centralised regulatory agency. Relevant governmental agencies treat targeted NGOs differently according to their own discretion. The two supervisory agencies, i.e., the professional/sectoral supervisor and the corresponding civil affairs bureau, are in immediate contact with the NGOs. In addition, at least three more categories of state actors are involved in monitoring NCO activities: public security agencies at the local level, local or national-level statistics, taxation, and other regulatory agencies, and last but not least, the state security agency.

Table 2 illustrates the detailed content of graduated state control over NCOs. When such control and regulation remain at low levels, the NGO submits progress reports, balance sheets, and other important organisational files to its sectoral supervising governmental agency and the civil affairs office upon request or on an infrequent basis, e.g., annually or bi-annually. Meanwhile, the NGO is seldom contacted by the district police station (paichusuo) or other relevant public security agencies. Even when contacted, such interaction is understood as part of regular checks by local public security agencies, for example, household registry and apartment leasing. No state agencies beyond the administrative level of the NGO's registration will ever interfere with its activities or request to meet its leaders.

When an NCO is listed under medium-level monitoring and control, both the professional and civil affairs supervisory offices will start contacting NCO staff much more frequently. Reports and meetings are requested every quarter or more regularly. At this stage, NGO staff, particular the founder(s) and the executive director(s), may experience personal warnings or harassment in written or verbal form by the local public security agencies. The NCO will receive requests to submit finances, legal documents, and organisational files to governmental agencies at higher level(s) of administration.
Recent cases from the field have shown that the State Bureau of Statistics has become a common player in monitoring those NGOs that have conducted cross-regional surveys or assisted foreign institutions' research in China. NGO practitioners may be "invited" for tea or meals by state security agents (referred by activists as qing he cha). The actual content of these tea sessions or meals can be ambiguous, but the indication is clear: The state knows what the $\mathrm{NCO}$ is doing.

The high level of control means document-based checks by sectoral supervisory agencies and the civil affairs bureau come by the month, week, or even more often. It is not uncommon at this stage for NGO staff to be asked to explain in detail their funding source(s), what kinds of foreign experts they are inviting, and what exactly they plan to do during a project. Official warnings may be sent in the form of a "red-letterhead file" (hongtou wenjian) charging the NGO with collaborating with foreign organisations to disturb social harmony. The worst scenario is that the supervisory agency will deny the necessary documents for renewing the NCO's legal status, which leads to temporary closure. The NGO and its staff may suffer increased pressure including but not limited to office raids by local police, charges of committing economic crimes or conducting illegal research, and temporary detention. Most NGOs will not continue to resist, and will close down at this point.

The above three levels are in a sense "ideal types" of NGO control. In practice, there is no definite institutional mechanism to coordinate various state agencies when monitoring and dealing with one particular NCO. At each stage, the NCOs do not necessarily undergo all types of interference by all relevant governmental agencies. Especially during the medium stage, which can last for a long while, different NCOs may experience very different interactions with state agencies. Some can experience consistent documentbased redress without being visited by either public security or state security officers. Some can receive serious requests from the state statistics and security agencies without any previous warning from the sectoral supervisors.

\section{NGO responses and dynamic government-NGO relations}

Not all NGOs suffer the same level of surveillance, nor does a single NGO experience unvarying attention from the government over time. While most service provision NGOs tend not to draw excessive interference from the state, and any NGOs that touch upon sensitive matters will immediately undergo a level of monitoring, for those NGOs situated in between (Category II in Table 1) the level of surveillance can fluctuate noticeably. As these Category II NCOs grow and expand their work, the initial level of governmental control may evolve and escalate. Table 3 introduces the temporal dimension of government-NGO interactions, and there follows an explanation of the various NGO responses to government control and how such responses further shape their relations with governmental agencies.

The meaning of "temporal dimension" is that relevant state agencies modify the level of interference over time, with all other factors remaining constant. This pattern is particularly true with regard to Category II NGOs that conduct both service delivery and some level of policy advocacy on nonsensitive topics. Because they are usually working in fields that do not generally cause offence and pose little apparent conflict with the CCP ruling ideology, e.g., gender equality in basic education, transportation and travel access for the disabled, and eliminating discrimination against Hepatitis B patients in job applications, they are mostly given enough space to develop 
Table 4 - NGO responses to governmental control (esp. Category II NGOs)

\begin{tabular}{|c|c|c|c|}
\hline \multicolumn{2}{|c|}{ Level of control } & NGO responses & Outcomes \\
\hline \multirow{2}{*}{ Low } & Follow the rules & & Remain low-level \\
\hline Medium & $\begin{array}{c}\text { Follow the rules, negotiate, } \\
\text { resist occasionally }\end{array}$ & B & Remain medium-level \\
\cline { 2 - 4 } & Resist until give in & & Escalate to high level \\
\hline High & NGO closed down \\
\hline
\end{tabular}

their work for an initial period of time. During this relatively stable period of growth, this group of NGOs can experience varying kinds of interactions with different governmental agencies. It is important to introduce the temporal dimension and to understand the dynamic nature of the governmentNGO power struggle.

The first one to two years for most Category II NGOs are free of stress. The pattern that the NGOs follow all the rules and regulations and their interactions with the government remain rare at this stage is by and large consistent across cases. However, as soon as they survive the most difficult initial period when resources are scarce, public recognition is low, and social networks are non-existent, they incur attention from various governmental agencies at the same time as they launch major projects and can almost see a bright future for their organisation and targeted population/community. This period of medium-level control and monitoring can last for five or even more years. Different NGOs interact, negotiate, and resist governmental pressure in different ways, depending on their leadership, organisational culture, and many other, unpredictable factors. In turn, governmental agencies may back off temporarily, or intensify the pressure. The outcome is not always constant. Once under high pressure and intense monitoring by the state, very few NCOs, as pointed out previously, can and/or will resist for long, and the pattern becomes clear again. Table 4 below highlights the general patterns of NGO responses to state control and the outcomes of their negotiation and resistance. To better explain the middle period, two recent field examples are given following the table.

Case $A$ is an environmental protection NGO with a strong background in student activism based in the capital city of a coastal province. ${ }^{(24)}$ The founding members started environmental activism when they were all in university at the end of the 1990s. They turned the student green group into an independent entity in 2001 with a small grant of US\$400 from an overseas foundation. Since 2004, the group has been commissioned by a bilateral assistance agency to take charge of a seed-fund for student environmental activism, first in the greater Yangtze Delta region, and later expanded to cover the entire country. Its annual budget increased significantly after 2007 and annual expenditure reached 170,000 RMB by 2012. The NGO has now four full-time staff (all in their twenties) and a Board of Directors consisting of the founding members, who are now recognised as "veteran" activists within environmental circles, and are wellrespected local environmental experts. Up to the present, the organisation has not obtained legal status as a social organisation from the local civil affairs bureau. Nevertheless, it has established its reputation nationwide among the most active environmental NCOs and university-based green groups.
Partially due to the fact that much of this NGO's work focuses on public environmental awareness-raising among youth, in spite of its foreign funding sources and lack of legal status, the government did not interfere with its organisational autonomy. However, the situation changed in the spring of 2011. After the municipal government announced a plan to uproot more than 600 street trees to make way for the construction of subway stations, NGO A utilised Internet-based mobilisation tools to call upon all residents of the city to protect these trees. Most of the street trees in the city are over a century old, and collectively they give the city a unique urban landscape. Soon after that, the local public security agency started to contact the NGO's executive director. Police officers called late at night and ordered the director to report to the district's police station. The director resisted this order and protested via micro-blog (weibo), explaining the whole incident and putting forward three main points:

1) What our organisation and I myself endeavour to accomplish is in the interests of all the people of our city. We have nothing to hide or be ashamed of;

2) We welcome everyone to check our documents when the time, place, and method are agreeable;

3) I do not feel safe walking late at night, and I hope the local police can respect my basic rights; if so, I am more than willing to cooperate.

The micro-blog got hundreds of hits and the word was out immediately. The local police sent someone to NGO A's office the next day and apologised to the director. When interviewed in May 2012, the director expressed mixed emotions of fear and courage on that night and informed us that the level of interference from the public security sector had been stable and had not intensified since that incident.

Case B focuses on rural development and works with a few villages in an inland province with a relatively low level of economic development. ${ }^{(25)}$ From the very beginning in the early 2000s, this NGO was established as an independent entity with a team of full-time staff and consistent foreign funding. By 2006, it had not only successfully registered as a non-government, non-profit organisation (minban fei qiye) with the municipal-level civil affairs bureau, but had also secured a good working relationship with its professional/sectoral supervisor. In 2007, the municipal Youth League recognised and awarded its accomplishments. In recent years, this NCO has also received a number of important awards within the civil society sector,

24. All identifying features of both Case $A$ and $B$ have been changed to protect the confidentiality and security of informants. The interview and site visit for Case A were conducted in May 2012.

25. The interview and site visit were first conducted in May 2009 and followed up in April 2012 
funded by major domestic donors and selected experts. It has become a leading group among all NGOs in its own province and neighbouring regions.

However, in the summer of 2011, its professional supervisory agency issued an official warning accusing the executive director of NGO B of "collaborating with foreign, anti-government forces" and "refusing to comply with relevant regulations." The warning prescribed a two-month deadline for the NGO, meaning that if it was not able to find a new supervisory agency its legal status would not be renewed. Given the circumstances and its record, it was impossible for the NGO to convince any other state agency to be its supervisory affiliation.

The executive director of NGO B explained that before the official warning, their supervisory agency pestered the NGO's staff with frequent requests for information on their funding, external relations, and biographical data of their advisors. Such requests started coming weekly or even daily, disrupting the NGO to the extent that office staff could no longer manage their regular work. In addition, staff members and volunteers felt high pressure at the individual level. Facing increasing pressure, the NCO mobilised all possible social capital and personal networks to find a way of communicating with supervisory agencies, in hopes of persuading them of the NGO's "political correctness." Eventually, this NGO discontinued its efforts and temporarily shut down its operations. (26)

Comparing the above two cases, both were under medium-level monitoring by the state when the dramatic events took place, but Case A's response and online protest led to a relatively positive result, while Case B failed to improve the situation. This paper is unable to explore systematically the possible causes and mechanisms for the state's counter-responses to an NGO's resistance to control and domination. However, a potential trend indicated by the above two cases is noted. Case A's open and confrontational micro-blog, instead of annoying the local authorities, resulted in apology and a subsequent smooth relationship. In sharp contrast, the NGO director of Case B tried more conventional, culturally sensitive methods of persuasion, but its attempts to "save face" for the government seemed to have little effect in alleviating the pressure. The state's decision to prioritise "social stability" in recent years may have played a role in determining specific treatment of various NGOs and incidents.

It is important to clarify that the state's interaction and interference with NGOs are inconsistent, if not oscillating, over time. In most cases, as the NGO grows, the level of state monitoring rises. During the stage of mediumlevel control, the power struggle between NCOs and governmental agencies reaches its peak. NGOs bear all the pressure and are able to mobilise their social support to resist to some extent. It is during this period that different NGO strategies and methods of resistance can lead to different outcomes in maintaining or escalating the intensive situation.

\section{Cooperation paralleling control: Local variations}

Besides exercising control, a few local Chinese authorities began to take proactive steps to encourage the development of social organisations within the parameters set by the central government in the early 2000s. The 2008 Sichuan earthquake marked a new era in civil society development in China. Since then, volunteerism, Internet-based charity activity, NGO establishment, and citizen participation in disaster relief and other areas have flourished across the country. ${ }^{(27)}$ Facing soaring activism under the name of "all people's philanthropy" (quanmin gongyi), the state recognised the urgent need to reform the regulatory system of civil affairs and social organisations. (28) Municipalities such as Beijing, Shanghai, Shenzhen, Guangzhou, and Chengdu were among the first to experiment with programmes of "innovation in social administration" (shehui guanli chuangxin). This policy concept was gradually confirmed by the central government and explicitly stated in a speech by President Hu Jintao in February 2011, setting the direction of social development at the national level as strengthening "party leadership, government responsibility, society's cooperation, and public participation." As pointed out by Ming Wang, Director of the NGO Research Institute at Tsinghua University, local governments have interpreted this "direction" in different ways by putting emphasis on either one or more of the four components. For example, Shenzhen has proposed "strengthening community building and innovating social administration," downplaying the idea of social control. Beijing and Chongqing, however, stressed "social administration and conflict resolution." (29) As "all politics is local," daily enforcement of the control policy is highly diverse across regions and deeply embedded in specific policy context. This section uses representative evidence from Sichuan and Gansu to illustrate how provincial governments vary in implementing NGO control, and how recent local experimentation with the concept of "innovation in social administration" could modify the contentious side of government-NGO relations to varying degrees.

The post-earthquake relief and reconstruction opened a rare window of opportunity for NGO and civil society development in Sichuan Province and beyond in 2008. Despite the authorities' change of attitude and shutting out of non-local volunteers or NGOs within six months, local Sichuan NGOs, especially those with some level of organisational capacity prior to the earthquake such as Chengdu Urban Rivers Research Group (Chengdu chengshi heliu yanjiuhui) and Roots and Shoots Chengdu (Gen yu ya), benefited from the relatively friendly policy environment. ${ }^{(30)}$ The ad hoc NGO platform for relief and reconstruction - the "5.12 Non-Governmental Relief Service Centre," established by a group of 30 grassroots NCOs (based in both Sichuan and beyond) on 13 May 2008 - has not only sustained its operation to date, but also obtained formal registration with the provincial government in early 2012. It has successfully transformed itself from a loosely connected action network to an institutionalised NGO specialising in natural disaster relief, reconstruction, and policy advocacy. Its current leaders, including a senior researcher of the Sichuan Provincial Academy of Social Sciences, Guo Hong, were invited to participate in policy consultations and were instrumental in drafting the new policies regarding NGO management and "innovation in social administration." (31) At the operational

26. By the time of publication of this paper, NGO B had resumed parts of its work without a legal status.

27. Yongguang $\mathrm{Xu}$, "Starting Year of China's Civil Society," http://politics.people.com.cn/ GB/1026/7336201 (published online 3 June 2008, accessed 25 June 2012) (in Chinese); Kin-man Chan, "The Rise of Civil Society in China," paper presented at the "China 2009 State of the Art" Conference, Brussels. 3-4 December 2009; Jessica C. Teets, "Post-Earthquake Relief and Reconstruction Efforts: The Emergence of Civil Society in China?," The China Quarterly, vol. 198, 2009, pp. 330-347; Shawn Shieh and Guosheng Deng, "An Emerging Civil Society: The Impact of the 2008 Sichuan Earthquake on Grass-Roots Associations in China," The China Journal, no. 65, 2011, pp. 181-94.

28. Karla W. Simon, "Regulation of Civil Society in China: Necessary Changes after the Olympic Games and the Sichuan Earthquake," Fordham International Law Journal, vol. 32, no. 3, 2009, pp. 94287.

29. Ming Wang, "The practice of innovation in social administration in Shanghai: Interview with Ma Yili," China Nonprofit Review, vol. 9, no. 1, 2012, pp. 1-14.

30. Interview with the director of Roots and Shoots Chengdu in Sichuan, 28 April 2012.

31. Interview with Guo Hong in Chengdu, 28 April 2012. 
level, NGOs strive to resist local governments' interference to maintain their organisational autonomy, reach those in need, and deliver care and service on a daily basis. In general, however, Sichuan NGOs acknowledge their space, yet limited, to work for the victims of the 2008 earthquake. ${ }^{(32)}$ Following this trend, the establishment of the Chengdu Social Organisation Development Fund to incubate more grassroots NGOs is explainable.

In contrast, many local NGOs have found the policy environment become more obstructive in Cansu Province in recent years. By 2008, a dozen grassroots NGOs were active in areas such as environmental protection, ethnic culture preservation, rural poverty relief, children's mental health, and rights for the disabled. Social gatherings, networking, and peer advising were common, and these NGOs enjoyed a sense of mutual trust and solidarity. However, in 2011, half of the NGOs went through vigilant checks and interference from various governmental agencies. By the end of the year, two NGOs decided to temporarily close down their work, and two others had not yet completed renewal of their registration. ${ }^{(33)}$ Although Gansu's provincial Bureau of Civil Affairs has started to experiment with new methods of engaging grassroots NGOs, other sectors of the provincial government remain highly conservative and lack sufficient knowledge of these organisations. Receiving funds from overseas organisations and donors is still viewed by many governmental agencies as a sensitive issue. ${ }^{(34)}$

Sichuan and Gansu to some degree represent the two ends of the spectrum with regard to government-NGO relations in China at the provincial level. Even with President Hu's speech in February 2011, local implementations of the policy direction "innovation in social administration" vary in pace and characteristics. Provinces such as Guangxi and Heilongjiang exhibit characteristics similar to Gansu, where NGOs face persistent political obstacles to enhancing their work quality. Governments in Guangdong and Shanghai, like those in Sichuan, have launched a consistent effort to strengthen the role of civil affairs bureaus in leading the reform of regulating social organisations. ${ }^{(35)}$

In provinces where the governments and political leaders have made political commitments to reforming the sector of social administration, there have been heated debates among officials and practitioners on how to improve the policy environment for NGOs. Many innovative policy ideas are being experimented with in different ways at the local levels, and thus may lead to varying results. One example is the task to establish linkage between governments and NGOs through intermediate organisations, and to develop the NGO sector through a government-recognised incubation agency. In Beijing, a new system of monitoring/supporting social groups through intermediate organisations was established under the framework of "categorised administration" (fenlei guanli). Similar to the practice legislated in the 1964 Provisional Regulation for Registration of Social Organisations, different GONGOs were assigned as umbrella intermediate organisations in specific issue areas to coordinate all existing and potential social organisations including NGOs. The Association for Science and Technology would be responsible for groups related to technology innovation or public scientific education, the Women's Federation for all groups related to women's issues, and the Youth League for any youth-related groups. In Shanghai, the municipal government established Service Centres for Social Organisations at different levels to serve an intermediate role in 2005. However, Ma Yili, current head of the Shanghai Bureau of Civil Affairs, pointed out that these intermediate organisations would just create another layer of authority and make the existing social administration system even more complicated. She has stated that what China really needs is more support organisations to help build the capacity of NGOs, ${ }^{(36)}$ and she has expressed appreciation and support for the Non-profit Incubator (NPI) founded independently by social entrepreneur Lu Chao without any governmental affiliation in the mid2000 s. NPI provides various services for social organisations, including training (developing a mission statement, personnel, and financial management), coaching (in fund applications), and official space for new organisations to kick-start their work.

Later, NPI was invited by local governments in Shenzhen and Beijing to replicate what was achieved in Shanghai. With the state retaining firm financial and political liaison from the beginning, NPI's autonomy is being highly questioned by the NGO and activist community in Shenzhen and Beijing. They argue that the NGOs incubated and supported by NPI are mostly service delivery groups, merely meeting the needs of the government without having an agenda of their own. In the context of rapid urbanisation and residential community development in these mega cities, NGO leaders expect that many more quasi-NGOs will be created by incubation agencies similar to NPI to fill gaps in welfare provision. In Chengdu, many leading grassroots NGOs remain cautious about the actual impact of the recently established Social Organisation Development Fund.

Enhancing public participation is another policy idea raised in recent policy documentation at the national level. Liu Runhua, former head of the Shenzhen Bureau of Civil Affairs and current standing deputy director of the Guangdong Social Work Committee, expressed in a conversation with one of the authors of this paper in May 2012 that his idea concerned not only social service reform but also public participation when he was involved in drafting the new policies related to "innovation in social administration." In his vision, the Provisional Method of Public Procurement of Services from Social Organisations discussed above would encourage governmental agencies to purchase services from social organisations to facilitate the delivery of its essential functions beyond basic services delivery, including specialised services such as legal assistance, policy (legislation) research, policy drafting, organising hearings, and deliberation on policy initiatives. (37) His views are undoubtedly among the most progressive within the Chinese state on the issue of public participation, and it remains to be researched whether Shenzhen's reform of the social administration will proceed as Liu has advocated. With the new policy direction of "innovation in social administration," some optimistic observers may expect a significant change in the political landscape of China when a great number of NGOs are incubated and equipped with legal status and resources in the near future. However, the preliminary as-

32. Interview with Mr. Wen, a social worker and director of the Yinxiu office of the Datong Association of Social Workers, in Yinxiu Township, Sichuan, on 29 April 2012. Interview with Ms. Kou, director of an NGO working with disabled children in a north-eastern county in Sichuan, in Hong Kong on 18 May 2012.

33. Interviews with Mr. Bai and Ms. Du of two different local Gansu NGOs, in Hong Kong in August 2011. Interview with Mr. Zhao of another local Gansu NGO, in Shenzhen on 27 April 2012.

34. Interview with an official of Gansu's provincial Bureau of Civil Affairs in Lanzhou, Gansu, on 27 July 2012.

35. Since July 2011, Wang Yang, the governor and Party secretary of Guangdong Province, has repeatedly highlighted the importance of "innovation in social administration" in many of his public speeches. In his most recent official visit to Singapore in June 2012, social administration was among the priority tasks for discussion and learning. See http://zt.my/News/NewsShow42054.html (consulted on 16 August 2012).

36. Ming Wang, "The Practice of Innovation in Social Administration in Shanghai: Interview with Ma Yili," China Nonprofit Review, vol. 9, no. 1, 2012, p. 12.

37. When Liu was still the bureau head in Shenzhen, he employed a private company to conduct public opinion surveys and hold public hearings to collect opinions during the policy formulation process. He promoted the slogan "growing together with civil society" and argued that the new governance model is needed to accommodate a pluralistic (duo yuan) society. 
sessment detailed in the above discussion implies that if civil society ideas and norms are not properly instilled in the incubation process, such innovations will reinforce the actual processes of control over NGOs without shaking the core of power domination in government-NGO relations.

\section{Conclusion}

This paper has detailed how the Chinese state has managed to keep NGO development under control in the past two decades. By assessing NGOs' work nature, funding sources, and scope of outreach, different governmental agencies interact with them on a graduated scale of monitoring and interference. NGOs are not passive when facing surveillance; they negotiate autonomy with supervisory governmental agencies and sometimes openly resist harassment by public security or state security agencies. Such reactions and resistance trigger further actions from the state, and thus modify the overall processes of control and management.

Entering the 2000s, local authorities in China have increasingly recognised the value of citizens' self-organised charity, mutual-help, and disaster relief activities, and the role of NGOs in leading such activities and taking part in social service delivery. Therefore, along with monitoring and control, some local governments have started experimenting with friendship policies to encourage the development of NCOs in social service delivery, community building, and public participation. This parallel control and cooperation has two main implications: First, the overall policy environment for NGO development in China is not one-dimensional but filled with ironies. For NGOs based in places such as Shanghai, Shenzhen, Chengdu, and Guangzhou, opportunities for growth and cooperation with the government will be accompanied by monitoring and interference. For others in most parts of the country, targeted and differentiated control will con- tinue in spite of new developments in national-level policy documents. Second, there is no guarantee that the cooperative policy innovations recently put in force will lead to flourishing grassroots NGOs. If implemented with conventional methods and administrative channels, so-called cooperative policies can quickly turn into new means of NGO co-optation. It will be the state, rather than the sector of NGOs and civil society, that will benefit most from these policies by inventing a group of quasi-NGOs whose sole mission is to take in retired bureaucrats, absorb resources, put up window-dressing, and reiterate official lines. Grassroots NGOs may in fact be further marginalized by losing out in the new game of competing for official funding and support.

Should NGOs register with the government and make themselves completely transparent to the state? Should NGOs bid for government projects and rely on state funding to sustain their operations? Should NGOs participate in the consultation mechanism of the state and refrain from adopting non-institutional and risky tactics in advocacy? These are questions and dilemmas that Chinese NGOs will face in the new era of innovation in social administration.

I Fengshi Wu is Associate Director of the Centre for Civil Society Studies, and Assistant Professor at the Department of Government and Public Administration of the Chinese University of Hong Kong.

3/F T. C. Cheng Bldg. The Chinese University of Hong Kong, Shatin, N.T., Hong Kong (wufengshi@cuhk.edu.hk).

I Kin-man Chan is Director of the Centre for Civil Society Studies and Associate Professor at the Department of Sociology of the Chinese University of Hong Kong.

4/F Sino Building, The Chinese University of Hong Kong, Shatin, N.T., Hong Kong (kmchan@cuhk.edu.hk). 